TUSSET, Igor Rocha; FORTES, Larissa Borges. As relações entre educação jurídica e poder: reflexões a partir do pensamento de Rousseau e Ranciére. Revista Eletrônica Direito e Política, Programa de Pós-Graduação Stricto Sensu em Ciência Jurídica da UNIVALI, Itajaí, v.10, n.3, $2^{\circ}$ quadrimestre de 2015. Disponível em: www.univali.br/direitoepolitica - ISSN 1980-7791.

\title{
AS RELAÇÕES ENTRE EDUCAÇÃO JURÍdICA E PODER: REFLEXÕES A PARTIR DO PENSAMENTO DE ROUSSEAU E RANCIÉRE
}

\author{
RELATIONS BETWEEN LEGAL AND POWER EDUCATION: REFLECTIONS \\ STARTING THOUGHT DE ROUSSEAU AND RANCIĖRE
}

\author{
Igor Rocha Tusset ${ }^{1}$ \\ Larissa Borges Fortes ${ }^{2}$
}

SUMÁRIO: Introdução; 1. Emílio ou da Educação; 2. O Mestre Ignorante; 3. Emilio ou do ensino superior emancipatório; Considerações Finais; Referências das Fontes Citadas.

\section{RESUMO}

Historicamente, as faculdades de Direito são responsáveis pela formação de boa parte dos ocupantes dos poderes de Estado e exerceram grande influência na formação da sociedade brasileira. A educação jurídica é submetida, desde sua origem, à regulação pelo próprio Estado. Nos últimos anos ocorreram mudanças significativas nas estruturas dos cursos, todavia, muitas relações de sala de aula se apresentam como relações de poder. Demanda-se analisar, a partir da perspectiva da Educação, como esta pode contribuir para a emancipação intelectual dos estudantes, de forma a representar uma evolução na atuação destes enquanto futuros agentes de Estado, em uma prática cada vez mais aproximada do ideal democrático.

PALAVRAS-CHAVE: Educação Jurídica; Emancipação; Democracia.

\section{ABSTRACT}

Historically, law schools are responsible about the formation of most of the occupants of the State's structure (Executive, Judiciary, Legislature, for example) and exerted great influence on social formation of Brazilian people. A legal

\footnotetext{
1 Mestrando em Direito pela IMED - Faculdade Meridional, linha de pesquisa "Fundamentos do Direito e da Democracia". Bolsista da FAPERGS (Fundação de Amparo à Pesquisa do Estado do Rio Grande do Sul). E-mail: igortusset@yahoo.com.br.

2 Mestranda em Direito pela IMED - Faculdade Meridional, linha de pesquisa "Fundamentos do Direito e da Democracia". E-mail: lari_bf@yahoo.com.br.
} 
TUSSET, Igor Rocha; FORTES, Larissa Borges. As relações entre educação jurídica e poder: reflexões a partir do pensamento de Rousseau e Ranciére. Revista Eletrônica Direito e Política, Programa de Pós-Graduação Stricto Sensu em Ciência Jurídica da UNIVALI, Itajaí, v.10, n.3, $2^{\circ}$ quadrimestre de 2015. Disponível em: www.univali.br/direitoepolitica - ISSN 1980-7791.

education is subjected, through its origin to regulation by the State. In recent years, this context have been significant changes in the structure of the courses, however, many classroom relationships are presented as power relations. So, it demands to analyze, through the Education, how it could contribute to the intellectual emancipation of students to represent an evolution in the role of these people as the future state agents in an increasingly rough of an ideal democratic practice.

KEYWORDS: Legal Education; Emancipation; Democracy.

\section{INTRODUÇÃO}

Conforme o Artigo 20, da Constituição Federal de 1988, são poderes da União: o Executivo, o Legislativo e o Judiciário. O Artigo 93, Inciso I, da CF/88, diz que o ingresso no quadro da magistratura é destinado aos bacharéis em direito, com a participação da Ordem dos Advogados do Brasil. Logo, um dos poderes de Estado é composto exclusivamente por egressos das faculdades de Direito. Ainda, entre as funções essenciais à justiça (Título IV, Capítulo IV, Seções I, II, III, da $\mathrm{CF} / 88$ ), estão as atividades do Ministério Público, Advocacia-Pública, Advocacia e Defensoria Pública. Todos, conforme suas respectivas leis orgânicas, restritivos aos bacharéis em Direito.

Para além de tais regulamentações, tem-se que, historicamente, grande parte dos ocupantes dos demais poderes de Estado também são egressos de faculdades de Direito. A própria instituição das faculdades de Direito em território brasileiro teve por escopo a formação de agentes para a atuação na organização do Estado, nas principais funções vinculadas ao poder. A História demonstrou que a formação vigente à época tinha um caráter excludente, voltada aos pertencentes de famílias que já exerciam o poder (político e econômico), segundo a estrutura social da época.

A organização da educação jurídica era absolutamente controlada pelo Estado. Privilegiava-se a contratação de professores que gozassem de grande 'prestígio' no meio jurídico. A relação que se estabelecera era a de que uma pessoa tida como um bom "prático", um profissional influente, seria um bom professor. 0 
TUSSET, Igor Rocha; FORTES, Larissa Borges. As relações entre educação jurídica e poder: reflexões a partir do pensamento de Rousseau e Ranciére. Revista Eletrônica Direito e Política, Programa de Pós-Graduação Stricto Sensu em Ciência Jurídica da UNIVALI, Itajaí, v.10, n.3, $2^{\circ}$ quadrimestre de 2015. Disponível em: www.univali.br/direitoepolitica - ISSN 1980-7791.

objetivo era, pois, a manutenção das relações de poder e a continuidade do modelo estatal.

Passaram-se décadas até que se tivesse alguma preocupação com a formação jurídica, a partir das bases da Educação. As reflexões acerca da educação jurídica são demasiadamente recentes para que se possam observar resultados concretos, nas práticas da vida profissional dos egressos. Diante desse contexto, onde grande parte dos agentes dos de Estado recebem uma formação específica (a jurídica) para o exercício das suas funções, é de suma importância que exista uma atenção especial voltada à educação jurídica. É na base da formação que se observa uma possibilidade de mudança de paradigma ou a manutenção do status quo, dentro das relações de poder em nossa sociedade.

O presente trabalho tem como objetivo verificar, a partir de duas obras que tratam da filosofia da educação, a influência das relações estabelecidas em sala de aula, entre professores e acadêmicos - especialmente as relações de poder estabelecidas a partir do modelo de ensino adotado -, nas atividades profissionais que dependam da formação em Direito, capazes de contribuir para o ideal democrático.

Tomar-se-á por base as reflexões extraídas das obras Emilio ou da Educação ${ }^{3}$, de Jean-Jacques Rousseau e 0 Mestre Ignorante ${ }^{4}$, de Jacques Rancière. A título de complementação, adotar-se-ão as contribuições de outras obras relacionadas aos temas propostos.

\section{EMÍLIO OU DA EDUCAÇÃO}

A obra Emilio ou da Educação foi publicada no ano de 1762, mesmo ano da publicação de 0 Contrato Social ${ }^{5}$. Pelo Contrato Social, Rousseau pretendia apresentar as bases da organização da sociedade. A organização das relações

\footnotetext{
${ }^{3}$ ROUSSEAU, Jean-Jacques. Emílio ou da Educação. Tradução de Sérgio Milliet. Rio de Janeiro: Bertran Brasil, 1995.

4 RANCIÈRE, Jacques. O Mestre Ignorante: cinco lições sobre a emancipação intelectual. Tradução: Lilian do Valle. Belo Horizonte: Auténtica, 2002.

${ }^{5}$ ROUSSEAU, Jean-Jacques. Do Contrato Social. Tradução: Rolando Roque da Silva. São Paulo: Hemus, 1981.
} 
TUSSET, Igor Rocha; FORTES, Larissa Borges. As relações entre educação jurídica e poder: reflexões a partir do pensamento de Rousseau e Ranciére. Revista Eletrônica Direito e Política, Programa de Pós-Graduação Stricto Sensu em Ciência Jurídica da UNIVALI, Itajaí, v.10, n.3, $2^{\circ}$ quadrimestre de 2015. Disponível em: www.univali.br/direitoepolitica - ISSN 1980-7791.

sociais não se dava pela imposição, ou pela força, mas de um pacto entre os homens. O Homem nasceria livre, em estado de natureza, mas entregaria parte de sua liberdade em prol da defesa de um interesse geral. Ao longo de quatro livros, a obra aborda os fundamentos da sociedade, da soberania, do governo e do sufrágio.

Rousseau inicia a obra Emilio ${ }^{6}$ deixando claro que adotará um tom afirmativo em suas considerações, pois parte de suas ideias e não das de outros, não sendo, pois, mais sábio que outro. Afirma que muitos acharão suas escritas devaneios, mas, ainda que suas ideias estejam erradas, se delas se conseguirem extrair boas ideias, já terá valido a pena. O centro de suas reflexões começa na criança, nas suas diversas fases de aprendizado. Refere: "Não se conhece a infância: com as falsas ideias que delas temos, quanto mais longe vamos, mais nos extraviamos. Os mais sábios apegam-se ao que importa que saibam os homens, sem considerar que as crianças se acham em estado de aprender" 7 .

Importante contextualizar que, à época das escritas de Rousseau, se ignorava a existência das fases de amadurecimento do ser humano, tais como a infância e a adolescência. E esse foi um dos caracteres revolucionários de sua obra: o reconhecimento da infância como fase de descobertas e aprendizado. Afirmava que os sábios procuravam um "homem" em uma criança, e isto era um grande equívoco.

Rousseau criticava o ensino da época. Dizia que o ensino visava moldar o homem por ele próprio, tal como o faz com as coisas da natureza. Pela educação (não pelo ensino da época), o sujeito seria capaz de adquirir tudo o que the fosse necessário na vida adulta. Nossos mestres seriam a natureza (e contra isto não se poderia agir de forma contrária), os homens (ser-se-ia relativamente seletivo quanto a isto) e as coisas (situação que dependeria exclusivamente da vontade).

Paiva ${ }^{8}$ refere que os métodos utilizados por Rousseau provocaram uma ruptura nas ideias pedagógicas:

\footnotetext{
${ }^{6}$ ROUSSEAU, Jean-Jacques. Emílio ou da Educação.

7 ROUSSEAU, Jean-Jacques. Emílio ou da Educação, p. 6.

8 PAIVA, Wilson Alves de. Homem e cidadão na obra pedagógica de Rousseau. In: Cadernos de Educação da FaE PPGE/ Universidade Federal de Pelotas (p. 163-184). Pelotas:
} 
TUSSET, Igor Rocha; FORTES, Larissa Borges. As relações entre educação jurídica e poder: reflexões a partir do pensamento de Rousseau e Ranciére. Revista Eletrônica Direito e Política, Programa de Pós-Graduação Stricto Sensu em Ciência Jurídica da UNIVALI, Itajaí, v.10, n.3, $2^{\circ}$ quadrimestre de 2015. Disponível em: www.univali.br/direitoepolitica - ISSN 1980-7791.

\begin{abstract}
A educação da natureza, que é o primeiro mestre, propicia a autoformação do jovem Emílio por meio do desenvolvimento de suas faculdades internas à medida que apreende o real. 0 segundo mestre, que é a educação dos homens, é o conjunto do preceptor, do hortelão e de todas as regras sociais que implicam uma heteroformação e uma preparação do convívio social. E, por fim, a educação que vem das coisas, o terceiro mestre, necessita dos objetos que possam afetar a sensibilidade do educando através dessa experiência empírica. Se tomarmos o episódio como uma lição no estrito senso do termo, os recursos metodológicos utilizados pelo pedagogo e a didática empregada para introduzir e desenvolver todo esse conteúdo provocam uma ruptura na história das idéias pedagógicas, servindo de base para o desenvolvimento da pedagogia da existência.
\end{abstract}

A educação mais básica competiria à mãe, por natureza. Rousseau identificou elementos da educação desde o momento do parto e dos primeiros contatos da mãe com a criança, prosseguindo sua análise pelos cuidados com o recémnascido e pela amamentação. A educação, em sua completude, seria uma arte, uma meta muito difícil de ser atingida. Muitas condições competiriam para o insucesso desta empreitada, inclusive fatores para além da ação humana. 0 objetivo seria aproximar-se o quão mais possível deste ideal.

Importante ser destacado que Rousseau distinguia a educação para a formação do homem e a formação para o convívio social (educação para os outros), sendo estas duas educações incompatíveis entre si. Nas palavras do Autor ${ }^{9}$ :

Quando, ao invés de educar um homem para si mesmo, se quer educá-lo para outros? Então o acerto se faz impossível. Forçado a combater a natureza ou as instituições, cumpre optar entre fazer um homem ou um cidadão, porquanto não se pode fazer um e outro ao mesmo tempo.

A educação para a vida civil transformaria os sujeitos em meras unidades fracionárias, cujos valores estão relacionados ao todo (o corpo social). O Homem, em seu estado natural, seria o oposto: seria tudo para ele próprio, e não para o corpo social. As instituições sociais serviriam para retirar esse estado

\footnotetext{
julho/dezembro 2008, p. $171-172 . \quad$ Disponível em: http://www2.ufpel.edu.br/fae/caduc/downloads/n31/09.pdf>. Acesso em 11.02.2014.

${ }^{9}$ ROUSSEAU, Jean-Jacques. Emílio ou da Educação, p. 12.
} 
TUSSET, Igor Rocha; FORTES, Larissa Borges. As relações entre educação jurídica e poder: reflexões a partir do pensamento de Rousseau e Ranciére. Revista Eletrônica Direito e Política, Programa de Pós-Graduação Stricto Sensu em Ciência Jurídica da UNIVALI, Itajaí, v.10, n.3, $2^{\circ}$ quadrimestre de 2015. Disponível em: www.univali.br/direitoepolitica - ISSN 1980-7791.

natural, e incutir no ser humano uma essência que não a sua, transformando o "eu" em uma unidade comum. Por conta desse processo, o sujeito não consegue se enxergar enquanto "eu", mas apenas como uma parte da unidade, não sendo mais sensível, senão no todo.

Os colégios da época eram, também, objeto da ira de Rousseau, o qual os classificava de "estabelecimentos ridículos". Reconhecia os méritos de muitos professores, mas tinha para si que estes não se desligavam da obrigação de obedecer aos métodos e usos pré-estabelecidos na sociedade. Ainda sobre a educação (em um modo geral), Rousseau esclarece que a o termo "educação" tinha, em sua origem, o sentido de "alimento". A pretensão de suas escritas era o de "ensinar a viver", para que o aluno pudesse escolher sua profissão, e não sofrer preconceito caso não escolhesse a profissão de seu pai. Todo aquele que recebesse a formação proposta seria capaz de exercer bem qualquer atividade.

A criança deveria, pois, ser educada para as variáveis do mundo, não para as condições de um só lugar, pois não resistiria, caso de lá saísse. A criança deveria sair preparada, quando adulta, para saber suportar todos os duros golpes que a sorte pudesse the reservar. Isto, para Rousseau, tolheria as limitações do bem viver. Para ele, era possível um ser humano ser enterrado aos cem anos, porém sem nunca ter vivido, como se tivesse sido melhor ter morrido antes, mas ter vivido, ao menos um pouco.

Numa pretensão de apresentar uma obra completa acerca do que seja a verdadeira educação, as considerações do Autor iniciam já acerca dos primeiros movimentos da criança recém-nascida, passando pela amamentação, cuidados maternos e primeiros passos. Aos seis ou sete anos a criança seria entregue a um preceptor, o qual seria responsável por sua educação.

Esclarece que o melhor preceptor seria o pai da criança. Quando isso não ocorre, a criança adquire afeto por um pai fictício, ainda que seja uma instituição, tal como, por exemplo, o pensionato, colégio, dentro outros. Nas palavras do Autor: "Será mais bem educado por um pai judicioso e limitado do que pelo mais hábil 
TUSSET, Igor Rocha; FORTES, Larissa Borges. As relações entre educação jurídica e poder: reflexões a partir do pensamento de Rousseau e Ranciére. Revista Eletrônica Direito e Política, Programa de Pós-Graduação Stricto Sensu em Ciência Jurídica da UNIVALI, Itajaí, v.10, n.3, $2^{\circ}$ quadrimestre de 2015. Disponível em: www.univali.br/direitoepolitica - ISSN 1980-7791.

preceptor do mundo, porquanto o zelo substituirá mais o talento do que o talento o zelo" ${ }^{10}$.

Rousseau não queria exercer a função de preceptor. Conta ter rejeitado a função de preceptor de um príncipe. Para narrar sua experiência, o autor criou um aluno imaginário, Emilio, o qual trabalharia sua educação, para servir de exemplo aos outros. Esse seria educado até ter a condição de educar-se por si próprio. A partir disto, Rousseau traz condições, inclusive físicas, para seu Emílio. Queria, por exemplo, que ele fosse sadio e robusto; o melhor clima para criar o menino seria o da França, dentre outras reflexões, próprias da época.

Falou sobre os hábitos, os gestos, os choros, a forma da fala, dentre outras análises, sempre interpretando segundo a relação das expressões da criança com o grupo social que o cerca. A partir do momento em que a criança tivesse vontade (que tivesse a consciência de suas vontades), ela poderia ser senhora de si mesma.

A obra em tela é dividida em cinco livros, tratando, cada um, de uma fase de desenvolvimento do homem, desde a infância. O segundo livro trata da fase imediatamente após o término da infância. Nesta fase, a criança necessita conhecer a dor, para poder suportá-la. Não a dor ao extremo, ao total descuido. Até as pequenas pancadas, tombos, facilitarão as noções dos limites corpóreos (até onde eu posso ir, sem colocar em risco minha integridade física). Essas descobertas devem ocorrer de forma espontânea. Nas palavras de Rousseau, "Nossa mania pedante de educar é sempre a de ensinar às crianças o que aprenderiam muito melhor sozinhas e esquecer o que somente nós lhes poderíamos ensinar"11. O bem estar da liberdade compensaria a dor de muitas machucaduras.

Aqui, Rousseau revela preocupação com a infância, situação inovadora para a época. Falava que o maior de todos os bens é a liberdade. Para ele, o homem realmente livre só desejaria o que pode e faria o que fosse capaz, sendo que esta máxima deveria ser aplicada à infância. Nesse caso, o meio mais seguro de mal

\footnotetext{
${ }^{10}$ ROUSSEAU, Jean-Jacques. Emílio ou da Educação, p. 24.

${ }^{11}$ ROUSSEAU, Jean-Jacques. Emílio ou da Educação, p. 59.
} 
TUSSET, Igor Rocha; FORTES, Larissa Borges. As relações entre educação jurídica e poder: reflexões a partir do pensamento de Rousseau e Ranciére. Revista Eletrônica Direito e Política, Programa de Pós-Graduação Stricto Sensu em Ciência Jurídica da UNIVALI, Itajaí, v.10, n.3, $2^{\circ}$ quadrimestre de 2015. Disponível em: www.univali.br/direitoepolitica - ISSN 1980-7791.

educar o filho seria acostumá-lo a tudo conseguir ${ }^{12}$, crescendo incessantemente seus desejos à medida da facilidade de satisfazê-los. À primeira recusa, a criança sentirá enorme aborrecimento, mais pela recusa, do que pela própria privação de seu objeto de desejo.

Atravessada a fase das primeiras cognições, da saída do estado de natureza para o contato com a vida em sociedade, a criança sentiria a necessidade de educação intelectual. Tanto que, conforme o Autor, a criança somente deverá aprender a ler quando aquilo Ihe for útil ${ }^{13}$. Antes, será somente mero aborrecimento.

O livro prossegue, de maneira bastante pormenorizada, falando sobre as descobertas sensitivas, o desenvolvimento das forças da criança, a sexualidade, a moral, as relações com outras pessoas, com Deus, entre outros. No último livro, Emilio encontra sua companheira, Sofia, também idealizada por Rousseau. O autor trata também sobre a importância das viagens, enquanto necessidade de conhecimento do mundo, para além dos livros. Por fim, são tecidas considerações sobre o direito político e as formas de governo. Fala sobre o casamento de Emilio e Sofia. Dentre suas últimas lições, está a leitura de Telêmaco e a recomendação de que Emílio siga seu caminho.

Para Rousseau, o ser humano é naturalmente bom, mas a sociedade (ou a má educação) o modifica para pior. O livro contém inúmeros conceitos já há muito superados pela sociedade, mas, guardadas todas as particularidades da época em que foi escrito, observa-se reflexões que demonstram a inovação, para a época, que Rousseau trouxe com seu Emilio.

A intenção de Rousseau era a de apresentar as bases do que seria uma formação de um homem ideal, capaz de lidar com todas as dificuldades que a vida em sociedade lhe possa apresentar. Antes de um cidadão ideal, a criança precisaria se transformar em um homem ideal. A obra, como já referido, foi inovadora ao reconhecer a infância e adolescência como fases importantíssimas para a vida do sujeito.

\footnotetext{
${ }^{12}$ ROUSSEAU, Jean-Jacques. Emílio ou da Educação, p. 71.

${ }^{13}$ ROUSSEAU, Jean-Jacques. Emílio ou da Educação, p. 110.
} 
TUSSET, Igor Rocha; FORTES, Larissa Borges. As relações entre educação jurídica e poder: reflexões a partir do pensamento de Rousseau e Ranciére. Revista Eletrônica Direito e Política, Programa de Pós-Graduação Stricto Sensu em Ciência Jurídica da UNIVALI, Itajaí, v.10, n.3, $2^{\circ}$ quadrimestre de 2015. Disponível em: www.univali.br/direitoepolitica - ISSN 1980-7791.

Emilio é tido por muitos como a primeira obra a tratar da pedagogia. Foi escrito há mais de duzentos e cinquenta anos. A sua leitura pode contribuir para as reflexões do ensino jurídico atual. A primeira reflexão ocorre acerca das críticas de Rousseau às instituições de ensino da época. Apesar dos esforços dos bons professores, o melhor ensino seria, inicialmente, o individualizado. As escolas obedeciam a métodos e usos pré-estabelecidos, o que não ocorreria com um preceptor.

Uma contribuição de Emilio é a preocupação do educador para a formação do educando para uma autonomia frente às variáveis do mundo. Ainda que as bases das reflexões de Rousseau sejam completamente inapropriadas (tal como o melhor lugar para a educação, por conta do clima, ou a análise primeira das condições físicas da criança), tem-se que a preocupação para a formação da independência do sujeito não difere de uma preocupação que se deva ter, hoje, na formação superior. Para Paiva ${ }^{14}$,

Claramente uma abertura ao universal, o Emílio não pode ser confundido e ignorado como um tosco ensaio literário do início do movimento romântico ou um mero devaneio filosófico. Mas deve ser encarado como a mais apaixonada proposta de dar respostas aos anseios de sua época que, inclusive, são também os mesmos anseios que temos na atualidade. Até porque os valores que caracterizam a sociedade atual, principalmente aqueles que emanam do binômio trabalho e eficácia econômica, bem como do binômio conhecimento e poder são praticamente os mesmos de outrora, diferindo apenas na maior intensidade e complexidade.

Emilio seria educado até ter condições de educar-se por si próprio. Até que isto ocorresse, ele deveria obedecer a seu preceptor. Com isto, duas reflexões se apresentam: o caminho do ensino individualizado para os métodos de ensino em grupos e o ensino voltado para a autonomia e a emancipação. Antes de se apresentar considerações acerca dessas reflexões no ensino superior (atualmente vigente), principalmente com relação a um possível ensino libertador, passa-se à análise da segunda obra proposta, O Mestre Ignorante ${ }^{15}$, de Rancière, que irá tratar de forma mais focada a questão da emancipação.

\footnotetext{
14 PAIVA, Wilson Alves de. Homem e cidadão na obra pedagógica de Rousseau, p. 171-172.

15 RANCIÈRE, Jacques. O Mestre Ignorante: cinco lições sobre a emancipação intelectual.
} 
TUSSET, Igor Rocha; FORTES, Larissa Borges. As relações entre educação jurídica e poder: reflexões a partir do pensamento de Rousseau e Ranciére. Revista Eletrônica Direito e Política, Programa de Pós-Graduação Stricto Sensu em Ciência Jurídica da UNIVALI, Itajaí, v.10, n.3, $2^{\circ}$ quadrimestre de 2015. Disponível em: www.univali.br/direitoepolitica - ISSN 1980-7791.

Coincidência ou não, se é com Telêmaco que Rousseau encerra sua obra, é com Telêmaco que Rancière inicia a sua.

\section{O MESTRE IGNORANTE}

Esta segunda obra analisada foi publicada originalmente no ano de 1987, aproximadamente duzentos e vinte e cinco anos após a publicação de Emilio. Narra a história de Joseph Jacotot, um professor francês que participou, ainda jovem, da revolução de 1789. Combatente efetivo da monarquia, lecionava em Dijon, na França. Chegou a ocupar o posto de deputado. Todavia, com o retorno dos Bourbons ao poder, acabou exilado nos Países Baixos.

No exílio, ocupou o posto de professor, lecionando meio período em Louvain, cidade próxima a Bruxelas. Como seu deslocamento não ocorreu por vontade própria, mas pelas circunstâncias, deparou-se com uma situação até então não imaginada: ele não sabia falar a língua holandesa. Como lecionar para uma turma que não compreendia a língua francesa?

Numa atitude de improviso, ele toma uma edição bilíngue de Telêmaco e, por meio de um intérprete, solicita aos estudantes que aprendam, por meio da tradução, o texto francês. Pediu aos estudantes a produção de um texto, em língua francesa, acerca do que pensavam sobre a leitura. Jacotot não tinha uma intenção definida. Não era um método que lhe fosse conhecido. Não esperava receber senão textos imprestáveis enquanto reflexão.

Para sua surpresa, os textos saíram tão bons como aqueles provindos de estudantes que dominassem a língua francesa. Esse resultado promovera uma profunda reflexão em Jacotot, acerca tudo o que já havia pensado a respeito de métodos pedagógicos. Todos os homens seriam, pois, capazes de compreender aquilo que outros já tenham feito e compreendido. Conforme refere o autor ${ }^{16}$ :

Mas, qual não foi sua surpresa quando descobriu que seus alunos, abandonados a si mesmos, se haviam saído tão bem dessa difícil situação quanto o fariam muitos franceses!Não seria, pois, preciso mais do que querer, para poder? Todos

\footnotetext{
${ }^{16}$ RANCIÈRE, Jacques. O Mestre Ignorante: cinco lições sobre a emancipação intelectual, p. 16.
} 
TUSSET, Igor Rocha; FORTES, Larissa Borges. As relações entre educação jurídica e poder: reflexões a partir do pensamento de Rousseau e Ranciére. Revista Eletrônica Direito e Política, Programa de Pós-Graduação Stricto Sensu em Ciência Jurídica da UNIVALI, Itajaí, v.10, n.3, $2^{\circ}$ quadrimestre de 2015. Disponível em: www.univali.br/direitoepolitica - ISSN 1980-7791.

os homens seriam, pois, virtualmente capazes de compreender o que outros haviam feito e compreendido?

Até aquele momento, Jacotot tinha a ideia de que a grande tarefa do mestre era a de levar seus conhecimentos até seus alunos, para elevá-los, gradualmente, à compreensão da ciência. O saber seria transmitido pelo sábio até o recebedor, o "não sábio". O espírito do "não sábio" iria progredir, do mais simples ao mais complexo, pela atividade do mestre. O ensino era, pois, vertical (de cima para baixo).

A primeira reflexão de Jacotot, após a situação vivenciada, foi: se os sujeitos são capazes de aprender sem a intervenção de um mestre, qual a utilidade desta figura? Após trinta anos de ensino, teria descoberto que sua tarefa era inútil?

Conforme as reflexões do personagem, a criança aprende a falar sozinha, segundo seus métodos. Inicia a balbuciar as primeiras palavras, vai exercitando, corrigindo, observando os demais, até que adquire condições de se manifestar, compreender e ser compreendida. Quando a criança chega na sala de aula, para o ensino segundo os métodos tradicionais, é tratada como se aqueles métodos de compreensão não tivessem mais validade. Os seus recursos de inteligência utilizados até aquele momento não servem mais.

Conclusão é a de que o explicador (ele próprio) pode constituir as incapacidades do aprendizado. O explicador cobre as coisas com "véu da ignorância" que ele pretende retirar. É essa justamente a lógica que precisa ser invertida. O ato de apresentar e impor a barreira do conhecimento é definido por Jacotot como "embrutecimento"17:

Há, segundo ele, uma inteligência inferior e uma inteligência superior. A primeira registra as percepções ao acaso, retém, interpreta e repete empiricamente, no estreito círculo dos hábitos e das necessidades. É a inteligência da criancinha e do homem do povo. A segunda conhece as coisas por suas razões, procede por método, do simples ao complexo, da parte ao todo. É ela que permite ao mestre transmitir seus conhecimentos, adaptando-os às capacidades intelectuais do aluno, e verificar se o aluno entendeu o que acabou de

\footnotetext{
17 RANCIĖRE, Jacques. O Mestre Ignorante: cinco lições sobre a emancipação intelectual, p. 20.
} 
TUSSET, Igor Rocha; FORTES, Larissa Borges. As relações entre educação jurídica e poder: reflexões a partir do pensamento de Rousseau e Ranciére. Revista Eletrônica Direito e Política, Programa de Pós-Graduação Stricto Sensu em Ciência Jurídica da UNIVALI, Itajaí, v.10, n.3, $2^{\circ}$ quadrimestre de 2015. Disponível em: www.univali.br/direitoepolitica - ISSN 1980-7791.

aprender. Tal é o princípio da explicação. Tal será, a partir daí, para Jacotot, o princípio do embrutecimento.

A interrupção do desenvolvimento da razão causa a destruição da confiança em si. O exercício de "compreender" é que seria o causador de todo o mal, levando ao processo de embrutecimento. O mestre observa qualquer dificuldade de compreensão e explica novamente, até que a criança compreenda. Essa prática hierarquiza a inteligência. A criança começaria a adquirir a "inteligência" das explicações do mestre, para transformar-se num explicador das explicações, e assim sucessivamente. A inteligência da criança passa a ser, na verdade, a inteligência do mestre.

Conforme o autor, Jacotot passou a seus alunos a tarefa de atravessar uma floresta da qual não conhecera a saída, diferindo das práticas de Rousseau ${ }^{18}$ :

Ele nada Ihes havia transmitido de sua ciência, nada explicado quanto aos radicais $e$ as flexões da língua francesa. Ele nem mesmo havia procedido à maneira desses pedagogos reformadores que, como o preceptor do Emilio,perdem seus alunos, para melhor guiá-los e balizam astuciosamente todo um percurso com obstáculos que precisam superar sozinhos. Ele os havia deixado sós com o texto de Fénelon, uma tradução - nem mesmo interlinear, como era uso nas escolas - e a vontade de aprender o francês. Ele somente Ihes havia dado a ordem de atravessar uma floresta cuja saída ignorava.

Dessa forma, o "compreender" equivale a uma tarefa de tradução. Não adentra o campo da razão das palavras e frases de um texto. Poder-se-ia aprender sozinho, sem um explicador, quando se quisesse. O desejo, ou as circunstâncias de uma determinada situação, poderiam ser a alavanca do aprendizado.

Inequívoco que a figura do mestre explicador era desnecessária. Mas, sem Jacotot, os alunos nunca teriam acessado o livro e apresentado seus textos. Sem o mestre, não havia aprendizado, ou seja, o professor havia thes ensinado algo. Havia, ainda, a liberdade da inteligência do aluno, com a inteligência do livro. Havia um laço entre o mestre e o aluno, uma relação igualitária, o livro.

${ }^{18}$ RANCIÈRE, Jacques. O Mestre Ignorante: cinco lições sobre a emancipação intelectual, p. 22. 
TUSSET, Igor Rocha; FORTES, Larissa Borges. As relações entre educação jurídica e poder: reflexões a partir do pensamento de Rousseau e Ranciére. Revista Eletrônica Direito e Política, Programa de Pós-Graduação Stricto Sensu em Ciência Jurídica da UNIVALI, Itajaí, v.10, n.3, $2^{\circ}$ quadrimestre de 2015. Disponível em: www.univali.br/direitoepolitica - ISSN 1980-7791.

Outra conclusão de Jacotot é a de que ocorre o embrutecimento quando uma inteligência é submetida a outra inteligência. O contrário do embrutecimento seria, pois, a emancipação ${ }^{19}$ :

Há embrutecimento quando uma inteligência é subordinada a outra inteligência. O homem - e a criança, em particular - pode ter necessidade de um mestre quando sua vontade não é suficientemente forte para colocá-la e mantê-la em seu caminho. Mas a sujeição é puramente de vontade a vontade. Ela se torna embrutecedora quando liga uma inteligência a uma outra inteligência. No ato de ensinar e de aprender, há duas vontades e duas inteligências. Chamarse-á embrutecimento à sua coincidência. [...] Chamar-se-á emancipação à diferença conhecida e mantida entre as duas relações, o ato de uma inteligência que não obedece senão a ela mesma, ainda que a vontade obedeça a uma outra vontade.

Jacotot observou que $\mathrm{o}$ ato de aprender poderia ser reproduzido segundo determinações diversamente combinadas: por um mestre emancipador ou por um mestre embrutecedor; por um mestre sábio ou por um mestre ignorante. Passou a fazer inúmeras experiências com suas descobertas. Chegou a ensinar pintura e piano, sem conhecer a fundo essas artes. Muitos passaram a buscar as aulas de Jacotot, apenas para ouvi-lo dizer: "é preciso que eu lhes ensine que nada tenho a Ihes ensinar"20.

Descobriu que se poderia ensinar o que se ignora, desde que emancipe o aluno, isto é, desde que se estimule o aluno a utilizar de sua própria inteligência e para que alguém se pretenda emancipador, deverá, antes de tudo, ser emancipado. Nessa proposição, até um pai de família (caso emancipado) poderia fazer a educação de seus filhos, sem o auxílio de qualquer explicador.

O aluno precisa formar a sua inteligência, e não reproduzir, indistintamente, aquilo que outros já disseram. O método ultrapassado não embruteceria os alunos por fazê-los soletrar, mas por impor-lhes a visão de que não poderiam soletrar sozinhos. O que embrutece o povo não é a falta de instrução, mas a crença na inferioridade dos saberes, de sua inteligência. Para ser emancipado, o

\footnotetext{
${ }^{19}$ RANCIÈRE, Jacques. O Mestre Ignorante: cinco lições sobre a emancipação intelectual, p. 2526.

${ }^{20}$ RANCIÈRE, Jacques. O Mestre Ignorante: cinco lições sobre a emancipação intelectual, p. 27.
} 
TUSSET, Igor Rocha; FORTES, Larissa Borges. As relações entre educação jurídica e poder: reflexões a partir do pensamento de Rousseau e Ranciére. Revista Eletrônica Direito e Política, Programa de Pós-Graduação Stricto Sensu em Ciência Jurídica da UNIVALI, Itajaí, v.10, n.3, $2^{\circ}$ quadrimestre de 2015. Disponível em: www.univali.br/direitoepolitica - ISSN 1980-7791.

sujeito precisa se reconhecer como sujeito comum, com as comuns capacidades dos seres intelectuais. Nas palavras do Autor ${ }^{21}$

O que pode, essencialmente, um emancipado é ser emancipador: fornecer, não a chave do saber, mas a consciência daquilo que pode uma inteligência, quando ela se considera como igual a qualquer outra e considera qualquer outra como igual a sua.

O método embrutecedor funciona como uma espécie de adestração. Todas as direções são dadas ao estudante, de forma que atingirá um destino que não havia previsto, seguindo por um caminho que ele não teria tomado por conta própria. Não há como denominar senão de insensatez a característica daqueles que propaguem a continuidade da dominação de uma inteligência sobre a outra. Para Rancière ${ }^{22}$ :

A inteligência não é potência de compreensão, que se encarregaria ela própria de comparar seu saber a seu objeto. Ela é potência de se fazer compreender, que passa pela verificação do outro. E somente o igual compreende o igual. Igualdade e inteligência são termos sinônimos, assim como razão e vontade.

As possíveis consequências do sistema de Jacotot criaram uma série de inquietações no ambiente francês. Os membros da sociedade chegavam ao ponto questionar sobre como as mulheres obedeceriam a seus maridos, já que as inteligências seriam iguais (tamanho o pensamento retrógrado da época). Por isso é que o poder da igualdade, uma vez reconhecida entre os homens, é capaz de promover momentos de razão dentro da loucura que é a sociedade em que se vive.

Todo aquele que consegue reconhecer que qualquer pessoa nasce para compreender o que qualquer homem tem a lhe dizer, reconhece a emancipação intelectual. Qualquer um pode, a todo instante, emancipar-se e emancipar a um

\footnotetext{
${ }^{21}$ RANCIÈRE, Jacques. O Mestre Ignorante: cinco lições sobre a emancipação intelectual, p. 50.

22 RANCIÈRE, Jacques. O Mestre Ignorante: cinco lições sobre a emancipação intelectual, p. 81.
} 
TUSSET, Igor Rocha; FORTES, Larissa Borges. As relações entre educação jurídica e poder: reflexões a partir do pensamento de Rousseau e Ranciére. Revista Eletrônica Direito e Política, Programa de Pós-Graduação Stricto Sensu em Ciência Jurídica da UNIVALI, Itajaí, v.10, n.3, $2^{\circ}$ quadrimestre de 2015. Disponível em: www.univali.br/direitoepolitica - ISSN 1980-7791.

outro. Quanto mais pessoas conhecerem este benefício, menos relações de inferioridade se estabelecerão ${ }^{23}$ :

Os tribunos que a plebe conquistou desrazoavam tanto quanto os outros. Apesar disso, o fato de que cada plebeu se sinta homem, se acredite capaz, acredite seu filho e qualquer outro capaz de exercer as prerrogativas da inteligência, isso é mais do que nada. Não pode haver um partido dos emancipados, uma assembléia ou uma sociedade emancipada. Mas todo homem pode, a cada instante, emancipar-se e emancipar a um outro, anunciar a outros esse benefício e aumentar o número de homens que se reconhecem como tais e não mais fazem de conta que são superiores inferiores. Uma sociedade, um povo, um Estado serão sempre desrazoáveis. Mas pode-se multiplicar o número de homens que farão uso, na condição de indivíduos, da razão e dominarão, na condição de cidadãos, a arte de desrazoar o mais razoavelmente possível.

O dever dos discípulos de Jacotot era simples: anunciar a todos, em qualquer lugar e circunstância, a boa nova: "pode-se ensinar o que se ignora"24. A pretensão daqueles que queriam levar adiante as conclusões de Jacotot não seria a de formar sábios; a real função destes seria a de elevar todos aqueles que se julgam inferiores em inteligência. O desafio seria fazê-los homens emancipados e emancipadores.

Qualquer professor não é nem mais nem menos inteligente que qualquer um. Aquele que tenha esta pretensão está, definitivamente, trilhando um caminho equivocado. A sua função é a de ofertar fatos à observação daqueles que procuram. Em 1827, Jacotot aceitou o convite do Rei dos Países Baixos (por influência do príncipe, apaixonado por Filosofia) e assumiu a coordenação pedagógica de uma escola normal militar. Essa atividade trilhou o rumo do insucesso. Jacotot era um emancipador, não um formador de instrutores militares.

Jacotot realmente não gostava dessa escola. Orientava aos militares que buscassem levar a sério o método e a levá-lo para seus filhos, que deveriam

${ }^{23}$ RANCIÈRE, Jacques. O Mestre Ignorante: cinco lições sobre a emancipação intelectual, p. 106.

${ }^{24}$ RANCIÈRE, Jacques. O Mestre Ignorante: cinco lições sobre a emancipação intelectual, p. 107. 
TUSSET, Igor Rocha; FORTES, Larissa Borges. As relações entre educação jurídica e poder: reflexões a partir do pensamento de Rousseau e Ranciére. Revista Eletrônica Direito e Política, Programa de Pós-Graduação Stricto Sensu em Ciência Jurídica da UNIVALI, Itajaí, v.10, n.3, $2^{\circ}$ quadrimestre de 2015. Disponível em: www.univali.br/direitoepolitica - ISSN 1980-7791.

ajudar os pobres, e não somente utilizar o método na formação de subalternos de guerra. A propósito, referia ele também que o método deveria ser levado, primeiramente, aos pobres, pois é sobre eles que pesa o maior preconceito da desigualdade da inteligência. Devem ser os primeiros a serem reerguidos da condição de humilhados.

Com a Revolução de 1830, Jacotot retornou a Paris, colocando-se à disposição de pais de famílias pobres para falar sobre o método de emancipar seus filhos. Para Jacotot, como se acreditava poder ensinar somente aquilo que se sabia, o verdadeiro sábio teria então o poder de decuplicar sua potência intelectual, pelo poder da emancipação. Nas lições do autor, a igualdade material é condicionada à emancipação intelectual ${ }^{25}$.

A crença na existência da desigualdade intelectual é o que define a visão embrutecedora do mundo. Seria desarrazoado acreditar que aqueles que se dizem (ou se creem) superiores são efetivamente superiores intelectualmente, e que, quanto maior difundida a ideia de que de que esta superioridade é apenas convencionada, maior risco correria a sociedade. Pelo contrário, somente um emancipado pode compreender que a ordem social é convencionada, e ainda sim obedecê-la. Já se sabe o funcionamento da ordem social. Os embrutecidos jamais saberão a realidade da ordem social.

Prosseguindo-se na narrativa, conta-se que diversas pessoas ouviram falar sobre o método e passaram a propagá-lo, em suas cidades, empresas e comunidades. Muitos se entusiasmaram com as ideias de Jacotot. O erro de Jacotot talvez tenha sido o de submeter seu método à Sociedade dos Métodos. Essa submissão representaria uma contradição: se o método pregava a ausência de hierarquias de saberes, por qual motivo teria reconhecido que aquela sociedade seria capaz de avaliar seu método. Seriam dotados de saberes notários?

Os membros daquela sociedade reagiram das mais diversas formas: alguns reconheceram os méritos de Jacotot; outros permaneceram céticos; outros, ainda, zombaram de Jacotot e de seu método simplificado de ensinar. Mesmo com essas reações diversas, fora concedido espaço a Jacotot na "Sociedade dos

${ }^{25}$ RANCIÈRE, Jacques. O Mestre Ignorante: cinco lições sobre a emancipação intelectual, p. 113. 
TUSSET, Igor Rocha; FORTES, Larissa Borges. As relações entre educação jurídica e poder: reflexões a partir do pensamento de Rousseau e Ranciére. Revista Eletrônica Direito e Política, Programa de Pós-Graduação Stricto Sensu em Ciência Jurídica da UNIVALI, Itajaí, v.10, n.3, $2^{\circ}$ quadrimestre de 2015. Disponível em: www.univali.br/direitoepolitica - ISSN 1980-7791.

Métodos". Situação paradoxal: se a Sociedade dos Métodos reconhecera o método de Jacotot, estaria reconhecendo, indiretamente, que todos os outros métodos estavam equivocados.

Alguns dos membros, porém, não compreenderam o que era o método de Jacotot, a exemplo de Lasteyrie, um criador de carneiros. Quando este tratou de anunciar a emancipação intelectual às famílias pobres, o fez de maneira completamente distorcida. Traduziu igualdade por progresso e emancipação de pais de família por "instrução do povo". Incutiu a ideia de que, para se ocupar desses seres de razão eram necessários outros seres de razão, uma sociedade erudita, uma universidade, entre outros, tudo o que contraria emancipação intelectual. Era o retorno ao embrutecimento.

Para o autor, é importante que fique claro, "a explicação é a obra da preguiça"26. A explicação é o embrutecimento, é o laço da ordem social, justificativa da hierarquização. Encontra sua justificativa em si mesma. O explicador é, ao mesmo tempo, dominador. Nessa linha de pensamento, jamais o aluno alcançará o "saber" de seu mestre; jamais um povo alcançará o "nível" de seus "esclarecidos".

Dentre esses mecanismos de manutenção desse status quo cita-se o escalonamento-hierarquização das explicações. Aquele século do progresso era, pois, o século dos explicadores triunfantes. Por mais que as situações se confundam com as atuais, devemos situar que se falava nos idos da primeira metade do século XIX. Os progressistas tinham a intenção de levar adiante esta libertação intelectual, mas o Velho (como Jacotot denominava o velho modelo de ensino) lutava para se manter em sua atividade embrutecedora.

Jacotot não era tolo a ponto de pregar que o total desconhecimento era condição de um bom ensino. Algumas instituições o seguiram, com um diferencial: seus professores conheciam profundamente as disciplinas (matemática, por exemplo) que lecionavam e, nem por isso, eram menos capazes de promover um ensino emancipador. Com o apoio que vinha recebendo, queria chegar à emancipação intelectual por meio do Ensino Universal. Para difundir suas ideias, lançou um

\footnotetext{
${ }^{26}$ RANCIÈRE, Jacques. O Mestre Ignorante: cinco lições sobre a emancipação intelectual, p. 123.
} 
TUSSET, Igor Rocha; FORTES, Larissa Borges. As relações entre educação jurídica e poder: reflexões a partir do pensamento de Rousseau e Ranciére. Revista Eletrônica Direito e Política, Programa de Pós-Graduação Stricto Sensu em Ciência Jurídica da UNIVALI, Itajaí, v.10, n.3, $2^{\circ}$ quadrimestre de 2015. Disponível em: www.univali.br/direitoepolitica - ISSN 1980-7791.

jornal e, para arrecadar fundos, criou uma sociedade: a "Sociedade Nacional Para a Emancipação Intelectual". Essa sociedade tinha a pretensão de que toda a sociedade francesa soubesse ler. E a instrução do povo, conforme se absorve das considerações a seguir, abala as bases de governos absolutos ${ }^{27}$.

Ao tratar sobre o que chamou de "o triunfo do velho", fala sobre um momento de tensionamento entre a emancipação intelectual e o 'velho', isto é, as velhas instituições que promovem o embrutecimento. As capacidades intelectuais ocupavam agora, na ordem social e política, o que antes equivalia aos títulos de nobreza. O 'velho' necessitava impedir que os pobres adquirissem a consciência de suas capacidades.

A forma de colocar em prática essa pretensão reacionária era a de incutir nos pobres a exata medida de suas incapacidades. Passaram a buscar estas pessoas, nos seus núcleos familiares, para 'instruí-las'. Diversas escolas eram inauguradas, mas todas sem a possibilidade de se aprender sem um mestre 'explicador'. Ninguém seria contrário à instrução do povo. Todavia, essa instrução seria "A direção de uma massa estúpida por uma casta inteligente"28, o que inverte completamente a lógica da emancipação.

O sistema cria uma lógica de desigualdade de inteligências e, ele mesmo, se propõe a corrigir esta desigualdade. A saída desta desigualdade seria a instrução pelos sábios. Dessa forma, o 'Velho' nunca sairá perdendo essa disputa.

Nesse contexto perverso, a proposta de Jacotot é a de cortar essa coleira. O desafio é o de fazer com que os sábios se libertem do ensino pautado em explicações e que os demais compreendam que, para aprender, não devem buscar estes sábios explicadores. Reconhece-se que, sem o golpe do acaso, Jacotot nunca teria acreditado e escutado essa teoria e a emancipação, para o professor francês, teria relação direta com a desigualdade ${ }^{29}(2002$, p. 138):

\footnotetext{
${ }^{27}$ RANCIÈRE, Jacques. O Mestre Ignorante: cinco lições sobre a emancipação intelectual, p. 130.

${ }^{28}$ RANCIÈRE, Jacques. O Mestre Ignorante: cinco lições sobre a emancipação intelectual, p. 136.

${ }^{29}$ RANCIÈRE, Jacques. O Mestre Ignorante: cinco lições sobre a emancipação intelectual, p. 138.
} 
TUSSET, Igor Rocha; FORTES, Larissa Borges. As relações entre educação jurídica e poder: reflexões a partir do pensamento de Rousseau e Ranciére. Revista Eletrônica Direito e Política, Programa de Pós-Graduação Stricto Sensu em Ciência Jurídica da UNIVALI, Itajaí, v.10, n.3, $2^{\circ}$ quadrimestre de 2015. Disponível em: www.univali.br/direitoepolitica - ISSN 1980-7791.

\begin{abstract}
Bastaria aprender a ser homens iguais em uma sociedade desigual - é isto que emancipar significa. Esta coisa tão simples é, no entanto, a mais difícil de compreender, sobretudo desde que a nova explicação - o progresso misturou, de forma inextricável, a igualdade e seu contrário. A tarefa à qual as capacidades e os corações republicanos se consagram é construir uma sociedade igual com homens desiguais, reduzir indefinidamente a desigualdade. Porém, quem tomou esse partido só tem um meio de levá-lo a tenho: a pedagogização integral da sociedade, isto é, a infantilização generalizada dos indivíduos que a compõem. Mais tarde, chamar-se-á a isso foonaçiio-contínua-coextensividade entre a instituição explicadora e a sociedade. A sociedade dos inferiores superiores será igual, ela reduzirá suas desigualdades, quando se houver transformado inteiramente em uma sociedade de explicadores explicados.
\end{abstract}

Para que o excluído da sociedade e das representações políticas busque a igualdade, ele precisa primeiro se reconhecer como igual. A igualdade (real) não é passível de ser posta ou reivindicada, ela é reconhecível, verificável. E a igualdade deve sempre se sobrepor.

Jacotot faleceu em 7 de agosto de 1840. Sob sua lápide seus filhos mandaram gravar o credo da emancipação intelectual: "Creio que Deus criou a alma humana capaz de se instruir por si própria, e sem mestres".

\title{
3. EMILIO OU DO ENSINO SUPERIOR EMANCIPATÓRIO
}

Rousseau desejava que Emilio estivesse pronto para a vida em sociedade. O "estar pronto" significava não sucumbir, de plano, às intempéries do meio social. Emilio estaria apto para exercer bem suas funções, quais fossem as atividades (principalmente as profissionais) que escolhesse. Por sua vez, Jacotot queria que todos fossem emancipados, de forma que o saber não representasse uma escala de poder.

Ambos desejavam, à sua maneira, que o destinatário de seus métodos não tivesse tolhida a sua independência intelectual. Em poucas linhas, a diferença entre estes seria que, de um lado, Rousseau pretendia apresentar o método que, 
TUSSET, Igor Rocha; FORTES, Larissa Borges. As relações entre educação jurídica e poder: reflexões a partir do pensamento de Rousseau e Ranciére. Revista Eletrônica Direito e Política, Programa de Pós-Graduação Stricto Sensu em Ciência Jurídica da UNIVALI, Itajaí, v.10, n.3, $2^{\circ}$ quadrimestre de 2015. Disponível em: www.univali.br/direitoepolitica - ISSN 1980-7791.

por excelência, seria capaz deste desiderato, para um sujeito idealizado; Jacotot, personagem de Rancière, pregava que a emancipação intelectual emana do próprio sujeito, e que todos possuem iguais inteligências, não podendo uma ser submetida hierarquicamente à outra.

Ambos, à sua maneira, demonstravam uma preocupação com a formação intelectual dos sujeitos, preocupação esta que guarda relação com as reflexões de hoje. Entende-se que muitas instituições de ensino superior acabam funcionando com a mesma lógica que as escolas de formação primária e média. Acabam representando uma mera continuidade entre estas duas 'fases' da formação.

Muitas relações podem ser feitas entre as lições de ambas as obras analisadas e o ensino fundamental, médio e superior dos dias de hoje. Ainda hoje, a criança, até o ingresso na escola, se vale de recursos de aprendizado que the são próprios. Aprende a falar e a andar segundo seus métodos, dentre outros aprendizados de grande profundidade.

Quando chega à escola, e esta escola possui como política a formação de sujeitos para a manutenção do status quo, acaba sendo quase que inevitável que a criança passe a entender que seus métodos de conexão/compreensão não são mais válidos, e que o saber é aquele saber transmitido verticalmente pelo professor explicador. Dessa forma, os seus recursos de inteligência são deixados de lado e não servirão mais àquele saber. O professor e o aluno acabam instituindo uma relação de saber-poder.

A emancipação, para Jacques Rancière, é busca pelo próprio caminho, conforme se observa na entrevista concedida pelo escritor francês a Vermeren, Cornu e Benvenuto ${ }^{30}$ :

A emancipação dos indivíduos deve, pois, ser pensada em um esquema inverso, no qual a vontade seja, não deixada de lado, para que se estabeleça a "pura" relação entre inteligências, mas, pelo contrário, se reconheça como tal, se declare como tal, isso é, se declare ignorante. O que é um

\footnotetext{
30 VERMEREN, Patrice; CORNU, Laurence; BENVENUTO, Andrea. Atualidade de O Mestre Ignorante. In. Revista Educação e Sociedade, vol 24, n. 82, p. 185-202. Campinas: abril de 2003. Disponível em <http://www.redalyc.org/pdf/873/87313720009.pdf>. Acesso em 18.02.2014.
} 
TUSSET, Igor Rocha; FORTES, Larissa Borges. As relações entre educação jurídica e poder: reflexões a partir do pensamento de Rousseau e Ranciére. Revista Eletrônica Direito e Política, Programa de Pós-Graduação Stricto Sensu em Ciência Jurídica da UNIVALI, Itajaí, v.10, n.3, $2^{\circ}$ quadrimestre de 2015. Disponível em: www.univali.br/direitoepolitica - ISSN 1980-7791.

mestre ignorante? É um mestre que não transmite seu saber e também não é o guia que leva o aluno ao bom caminho, que é puramente vontade, que diz à vontade que se encontra a sua frente para buscar seu caminho e, portanto, para exercer sozinha sua inteligência, na busca desse caminho.

Mudanças estão ocorrendo, é inegável, e os efeitos das práticas 'em mudança' se propagam por grande período. E se se afirma que a lógica do ensino escolar é, muitas vezes, repetida pelas instituições de ensino superior, inegável que o efeito seja o mesmo: o ensino embrutecedor e uma relação de saber/poder de um mestre explicador dentro da academia.

Essa forma de ensino, de imposição de informações, segue a mesma lógica da troca de informações em massa em nossa sociedade. Todos os dias existe um bombardeio de informações sobre a quase totalidade das coisas da vida. Muitas informações nos são transmitidas já com uma reflexão formatada sobre quais considerações devemos carregar conosco sobre aquele determinado fato. A pessoa recebe o fato e já recebe qual o juízo deve emitir sobre aquele fato.

Aqui importa trazer as reflexões de Warat $^{31}$, para o qual:

[...] Todo processo de ensino deve visar à preservação de nossa capacidade de engajamento numa práxis transformadora. Por isso, na base do ato pedagógico devemos encontrar 0 estímulo à criatividade, o entusiasmo pela vida, e uma trama de afetos. [...] A prática dos juristas unicamente será alterada na medida em que mudem as crenças matrizes que organizam a ordem simbólica desta prática. A pedagogia emancipatória do Direito passa pela reformulação de seu imaginário instituído.

Essas relações, como observado, envolvem relações de poder e de manutenção da situação posta. Esta lógica não reflexiva pode se instalar, como afirmado, desde os bancos do primário, até os bancos das instituições de ensino superior.

\footnotetext{
31 WARAT, Luis Alberto. Territórios desconhecidos: a procura surrealista pelos lugares do abandono do sentido e da reconstrução da subjetividade. coord.: Orides Mezzaroba, Arno Dal Ri Júnior, Aires José Rover, Cláudia Sevilha Monteiro. Florianópolis: Fundação Boiteux, 2004a, p. 258.
} 
TUSSET, Igor Rocha; FORTES, Larissa Borges. As relações entre educação jurídica e poder: reflexões a partir do pensamento de Rousseau e Ranciére. Revista Eletrônica Direito e Política, Programa de Pós-Graduação Stricto Sensu em Ciência Jurídica da UNIVALI, Itajaí, v.10, n.3, $2^{\circ}$ quadrimestre de 2015. Disponível em: www.univali.br/direitoepolitica - ISSN 1980-7791.

Nesse quadro, qualquer educador que se apresentar como senhor da verdade deve ser apontado como impostor. Rancière, na entrevista antes referida, diferencia as proposições de seu livro ao método de Paulo Freire e relaciona a emancipação intelectual ao próprio exercício da democracia. Para Rancière as ideias de Jacotot são uma oposição à concepção da educação como forma de ordenar a sociedade ${ }^{32}$ :

Quando eu penso em Paulo Freire, a primeira coisa que me ocorre é sua distância em relação à divisa comtista na bandeira brasileira, "ordem e progresso": é como uma transposição da relação de Jacotot para com os educadores progressistas - oposição entre uma concepção da educação destinada a ordenar a sociedade e um pensamento da emancipação que vem interromper essa harmonia suposta entre a ordem progressiva do saber e a ordem de uma sociedade racional progressiva. Há, então, uma espécie de atualidade de Jacotot no Brasil, no sentido de que o Brasil é o único país a ter feito da ideologia pedagógica do século XIX a própria palavra de ordem de sua unidade nacional.

Muitos são os Emilios que buscam a faculdade de Direito. Emilio pode ter dezessete anos ou quarenta e nove. Pode ter filhos ou não. Pode ter emprego ou não. Pode estudar à noite e estar cansado do trabalho. Pode ter muitos sonhos. Pode não ter dinheiro para pagar a faculdade. Pode ter uma alfabetização limitada.

Ou seja, diferentemente de Rousseau, não existe uma figura idealizada de um estudante apto a receber a formação ideal. Muitos são os Emilios, cada qual com suas particularidades. Essa diversidade configura as dificuldades e as riquezas da missão que o educador do Direito tem enquanto possível facilitador de emancipação. A própria compreensão do que seja o fenômeno do Direito passa pela compreensão das relações sociais nas quais esteja inserido, conforme se depreende das palavras de Mascaro $^{33}$ :

\footnotetext{
32 VERMEREN, Patrice; CORNU, Laurence; BENVENUTO, Andrea. Atualidade de O Mestre Ignorante, p. 14.

33 MASCARO, Alysson Leandro. Introdução ao Estudo do Direito. São Paulo: Quartier Latin, 2007, p. 51.
} 
TUSSET, Igor Rocha; FORTES, Larissa Borges. As relações entre educação jurídica e poder: reflexões a partir do pensamento de Rousseau e Ranciére. Revista Eletrônica Direito e Política, Programa de Pós-Graduação Stricto Sensu em Ciência Jurídica da UNIVALI, Itajaí, v.10, n.3, $2^{\circ}$ quadrimestre de 2015. Disponível em: www.univali.br/direitoepolitica - ISSN 1980-7791.

\begin{abstract}
Assim sendo, as disputas sobre a definição do que seja direito revelam também, mais profundamente, as concepções de mundo, as ideologias e, principalmente, as posições sociais e de classe daquelas que lidam com 0 fenômeno jurídico. Não há uma concepção "pura" ou neutra do que seja direito. Toda concepção envolve, na verdade, uma perspectiva particular, uma situação histórica, social e ideológica daquele que define. Não há uma neutra ciência do direito. Toda definição do direito é ideológica, ainda que quando ela se diga "pura" ou não ideológica. E toda ciência do direito é, pois, uma interpretação sobre fatos e ideias, respaldada, com mais ou menos habilidade, em informações de outras ciências, fatos e idéias.
\end{abstract}

Ainda que sob todas as intempéries da realidade posta, se a missão do educador do Direito não for o ensino emancipador, sua missão será em vão. Melhor desempenho seria atribuído aos manuais e resumos, pois estes podem vir a ser menos instigantes e embrutecedores. Esta crise do ensino do Direito passa pela própria crise da ciência e do conhecimento, conforme apresenta Boaventura de Sousa Santos ${ }^{34}$. Para ele, o conhecimento representa o caminho percorrido entre um estado de ignorância e o saber.

A Modernidade apresenta duas formas de conhecimento; uma o "conhecimentoemancipação" e outra o "conhecimento-regulação". O conhecimento-regulação é o caminho entre um estado de caos e um estado de ordem. Por sua vez, o conhecimento-emancipação é o caminho entre um estado de colonialismo e um estado de solidariedade.

Todavia, o conhecimento-regulação teria se sobreposto ao conhecimento emancipação, pelas lógicas da racionalidade, e a ordem passou a ser tida como forma hegemônica do saber. A solidariedade passou a ser considerada caos. Esta lógica permeou a ascensão do Direito, conforme refere Sousa Santos ${ }^{35}$ :

\footnotetext{
34 SANTOS, Boaventura de Sousa. A crítica da razão indolente: contra o desperdício da experiência. 4 ed. São Paulo: Cortez, 2002.

35 SANTOS, Boaventura de Sousa. A crítica da razão indolente: contra o desperdício da experiência. 4 ed. São Paulo: Cortez, 2002, p. 134.
} 
TUSSET, Igor Rocha; FORTES, Larissa Borges. As relações entre educação jurídica e poder: reflexões a partir do pensamento de Rousseau e Ranciére. Revista Eletrônica Direito e Política, Programa de Pós-Graduação Stricto Sensu em Ciência Jurídica da UNIVALI, Itajaí, v.10, n.3, $2^{\circ}$ quadrimestre de 2015. Disponível em: www.univali.br/direitoepolitica - ISSN 1980-7791.

No novo contexto sociológico oitocentista de domínio do capitalismo, do nacionalismo e do imperialismo, a cientificização do direito permitida pelo direito romano transformado, entretanto, numa erudição inútil e num esoterismo impenetrável - demonstra como, num período de hegemonia positivista, a regulação social se torna científica para ser maximizada e para, de passo, maximizar o esquecimento da ética social e política que, desde o século XII, mantivera vias as energias emancipatórios do novo horizonte jurídico. A tensão, muito particular, entre regulação e emancipação que caracterizou a recepção do diremos romano era parte integrante do projeto historio da nova burguesia eropeia, em luta de pela conquista do poder econômico e cultural e, por último, do poder político. Uma vez conquistado o poder político, essa tensão perdeu toda a utilidade histórica.

O ensino fracionado, onde o professor incute o saber já elaborado no estudante, estabelece uma relação de poder, da qual o acadêmico se tornará submisso e dependente. Representa a reprodução de um círculo vicioso. A forma de pensar o Direito voltado à transformação social deve compor a formação do jurista, conforme assinala Souza Júnior ${ }^{36}$ (2006, p. 20):

[...] Ao fim e ao cabo, condições para superar a distância que separa o conhecimento do Direito de sua realidade social, política e moral, possibilitando a edificação de pontes sobre o futuro através das quais pudessem transitar os elementos novos de apreensão e compreensão do Direito e de um novo modelo de ensino jurídico.

Tratava-se, como se vê, de empreender um trabalho crítico e consciente apto a afastar o jurista das determinações das ideologias, quebrar a aparente unidade ou homogeneidade da visão de mundo constitutiva de um apensamento jurídico hegemônico produzido por essas ideologias e romper, em suma, com a estrutura do modo abstrato de pensar o direito, inapto para captar a complexidade e as mutações das realidades sociais e políticas.

O ensino do Direito deve ser capaz de promover espaços de emancipação, de forma que o egresso possa multiplicar espaços de emancipação (formação de sujeitos emancipados e emancipadores), em sua prática posterior ao curso.

${ }^{36}$ SOUZA JÚNIOR, José Geraldo de. Ensino do Direito e Assessoria Jurídica. In. Revista do Saju: Para uma visão crítica e interdisciplinar do direito. Ed. Especial n. ${ }^{\circ}$ 5. Porto Alegre: Faculdade de Direito da UFRGS, 2006, p. 20. 
TUSSET, Igor Rocha; FORTES, Larissa Borges. As relações entre educação jurídica e poder: reflexões a partir do pensamento de Rousseau e Ranciére. Revista Eletrônica Direito e Política, Programa de Pós-Graduação Stricto Sensu em Ciência Jurídica da UNIVALI, Itajaí, v.10, n.3, $2^{\circ}$ quadrimestre de 2015. Disponível em: www.univali.br/direitoepolitica - ISSN 1980-7791.

Como o Direito trata com questões fundamentais da vida dos sujeitos, é preciso que se compreenda que a emancipação dos sujeitos é fundamental. Uma educação emancipadora é capaz de formar um profissional que possa exercer uma atividade emancipadora.

A busca de mudanças no panorama do ensino jurídico no Brasil não deve perder de vista a sua origem, suas raízes. Desde a instituição dos primeiros cursos de Direito no Brasil, o objetivo era o de formar aqueles que iriam se relacionar com o poder estatal, seja na condição de magistrados, seja como componentes do Poder Legislativo.

A criação destas instituições era destinada justamente para aqueles (principalmente famílias) que já exerciam o poder ou forte influência na sociedade. A existência destes cursos surgia, em verdade, para uma manutenção das relações de poder estabelecidas no cenário político e econômico brasileiro. 0 sujeito era formado para a manutenção daquela situação, daquele status quo. Ao tratar da trajetória da cultura jurídica brasileira, Wolkmer ${ }^{37}$ assim leciona:

A partir da compreensão de que toda criação jurídica reproduz determinado tipo de relações sociais envolvendo necessidades, produção e distribuição, torna-se natural perceber a cultura jurídica brasileira como materialização das condições histórico-políticas e das contradições sócioeconômicas, traduzidas, sobretudo, pela hegemonia das oligarquias agroexportadoras ligadas aos interesses externos e adeptas do individualismo liberal, do elitismo colonizador e da legalidade lógico-formal.

Nessa condição, inclusive, que os símbolos assumiam papel de destaque na formação, tais como as formalidades das solenidades de formatura, o uso dos anéis de bacharéis ${ }^{38}$, as vestes, entre outros. Conforme relata Hollanda ${ }^{39}$, o bacharelismo sempre esteve associado a bons rendimentos e à ascensão aos

\footnotetext{
37 WOLKMER, Antônio Carlos. Pluralismo Jurídico: Fundamentos de uma nova cultura no Direito. 3 ed. São Paulo: Alfa-Omega, 2001, p. 84.

38 O Decreto n.o 3.903, de 12.01.1901, regulamentou as faculdades de Direito, sendo que em seu Art. 43, previa as distinções destinadas aos que obtivessem os graus de bacharel e de doutor, tais como o anel de rubi e o uso da beca.

39 HOLLANDA, Sérgio Buarque de. Raízes do Brasil. 26 ed. São Paulo: Companhia das Letras, 1995, p. 157.
} 
TUSSET, Igor Rocha; FORTES, Larissa Borges. As relações entre educação jurídica e poder: reflexões a partir do pensamento de Rousseau e Ranciére. Revista Eletrônica Direito e Política, Programa de Pós-Graduação Stricto Sensu em Ciência Jurídica da UNIVALI, Itajaí, v.10, n.3, $2^{\circ}$ quadrimestre de 2015. Disponível em: www.univali.br/direitoepolitica - ISSN 1980-7791.

graus de poder. Muitos presidentes, à exceção dos generais, eram, antes advogados.

O prestígio em torno do bacharelismo é herança portuguesa, conforme relata o referido autor: "Em quase todas as épocas da história portuguesa uma carta de bacharel valeu quase tanto como uma carta de recomendação nas pretensões a altos cargos públicos" ${ }^{\prime 40}$.

Mesmo com as reformas educacionais que se sucederam no tempo, é importante que se reflita sobre qual o tipo de ensino jurídico que possuímos hoje e quais as influências daqueles objetivos iniciais permeiam até os dias de hoje. Como este estudante é forma(ta)do para ser "colocado" no funcionamento da sociedade. É preciso formar o sujeito para ser útil ao funcionamento da sociedade, ou para ser um sujeito reflexivo em relação à nossa sociedade?

Por isso, é chamada a atenção para a relação de poder que se estabelece dentro de sala de aula. O professor pode estabelecer uma relação de poder sobre o estudante. A consequência é que aquele que é submetido a uma relação de poder normalmente busca ocupar este lugar de poder. Isso acaba chegando até sua prática profissional. Por exemplo, o advogado que não enxerga o outro como capaz de resolver o próprio conflito. Assume uma relação de poder sob seu cliente, tornando-se o senhor da pretensão de seu constituído.

O modelo paternalista e hierarquizado do exercício da advocacia é assim descrito por Campilongo ${ }^{41}$ :

O modelo tradicional de serviços legais - individualista, paternalista e assistencialista - pressupõe uma relação hierarquizada entre advogados e clientes, complementada pela postura apática e passiva dos segundos. O formalismo no atendimento à clientela vai, através de uma série de índices, estabelecendo uma subordinação do cliente ao saber profissional. Da indumentária ao vocabulário, do local de atendimento à postura na relação dialógica, do manuseio dos Códigos ao diploma pendurado na parede, tudo cria um ambiente desconhecido e enigmático para a cliente. A gravata, o

\footnotetext{
${ }^{40}$ HOLLANDA, Sérgio Buarque de. Raízes do Brasil, p. 157.

${ }^{41}$ CAMPILONGO, Celso Fernandes. O Direito Na Sociedade Complexa. São Paulo: Max Limonad, 2000, p. 21-22.
} 
TUSSET, Igor Rocha; FORTES, Larissa Borges. As relações entre educação jurídica e poder: reflexões a partir do pensamento de Rousseau e Ranciére. Revista Eletrônica Direito e Política, Programa de Pós-Graduação Stricto Sensu em Ciência Jurídica da UNIVALI, Itajaí, v.10, n.3, $2^{\circ}$ quadrimestre de 2015. Disponível em: www.univali.br/direitoepolitica - ISSN 1980-7791.

palavreado difícil, a sala acarpetada, o problema constrangedor (a separação, o despejo, o crime) os livros e a autoridade técnica do bacharel determinam o lugar de quem fala e quem ouve. [...] Os tecnicismos dos procedimentos judiciais, aliados à demora dos processos, tornam o cliente anestesiado diante da lide.

Boa parte deste desvirtuamento decorre da forma como ocorre o ensino do Direito, quase que de forma primária, jesuítica. O Direito acaba sendo ensinado distante da realidade. O desafio do educador que se pretenda emancipador é o ensino crítico, a partir de novos conceitos, diferentemente da forma tradicional. Nesse ponto, importante citar Warat ${ }^{42}$ :

Não adianta que um professor organize suas aulas a partir de um tema, estabelecendo argumentos. Desse jeito os professores conseguirão a produção de saberes bastante artificiais, bastante forçados. Hoje começa a ser rejeitada a ideia de que a função do professor é a de ensinar. Atualmente considera-se que os professores são meros ajudadores (facilitadores), que assistem as pessoas para aprender. Nenhum professor ensina, unicamente ajuda as pessoas a aprenderem. Isto começa a ser uma afirmação com tendência a ser pacificamente aceita pela comunidade dos acadêmicos.

Observou-se que o terceiro mestre de Emilio era a empiria. Esse mestre eram as coisas do mundo, os objetos, aquilo que pudesse afetar a sensibilidade do educando. A partir dessa metáfora, sugere-se que, para que o ensino do Direito possa representar uma atividade emancipadora, cada vez mais o acadêmico necessita deste mesmo terceiro mestre de Emilio. Necessita que o aprendizado esteja relacionado à realidade que o circunda.

Caso contrário, estar-se-á formando meros sabedores de leis. É preciso que se reflita, inclusive, se a introdução do exame de submissão dos bacharéis em direito à prova da Ordem dos Advogados do Brasil contribuiu para esta mudança

\footnotetext{
42 WARAT, Luis Alberto. Epistemologia e ensino do direito: o sonho acabou. coord.: Orides Mezzaroba, Arno Dal Ri Júnior, Aires José Rover, Cláudia Sevilha Monteiro. Florianópolis: Boiteux, 2004b, p. 98.
} 
TUSSET, Igor Rocha; FORTES, Larissa Borges. As relações entre educação jurídica e poder: reflexões a partir do pensamento de Rousseau e Ranciére. Revista Eletrônica Direito e Política, Programa de Pós-Graduação Stricto Sensu em Ciência Jurídica da UNIVALI, Itajaí, v.10, n.3, $2^{\circ}$ quadrimestre de 2015. Disponível em: www.univali.br/direitoepolitica - ISSN 1980-7791.

de foco que se ensaiava, ou se a forma de ensino sempre manteve uma mesma lógica.

Nos dias atuais, as questões da prova da OAB são objeto de estudo das disciplinas em sala de aula. Fora destes conteúdos, o estudante não saberia qual caminho buscar para a construção do conhecimento jurídico. Ou seja, a prova da OAB representa igual força no sentido de manutenção do status quo. Entretanto, o estudante de Direito que não passa pela experiência da emancipação, desconhecerá a possibilidade de buscar a emancipação daqueles com quem se relaciona, não contribuindo para uma mudança saudável do paradigma da sociedade, com todas suas mazelas. Quanto maior o acesso dos sujeitos de direitos à emancipação, melhor relação estes terão com os poderes de Estado, melhor ocorrendo a oxigenação das estruturas da Democracia.

Este estudante acredita ter a capacidade de assumir o destino daqueles com quem relacionar suas atividades profissionais. É preciso que se rompa com a lógica do ensino do Direito como forma de manutenção das relações de poder na sociedade. Nada impede, nem a prova da OAB, que o ensino emancipatório seja praticado dentro da sala de aula, na faculdade, pois esses mesmos Emilios acabam assumindo cargos enquanto poderes de Estado e suas práticas frequentemente serão relacionadas àquilo que foi objeto de sua formação.

\section{CONSIDERAÇÕES FINAIS}

As reflexões trazidas no presente ensaio permitem concluir que os preceitos da Educação são de valia para a avaliação do ensino do Direito e para a proposição de mudanças estruturais necessárias.

Mesmo que as considerações se deem a partir das obras propostas, não se pretende o ensino do Direito de forma individualizada, como Rousseau objetivava seu modelo de ensino ideal, tampouco se pretende a adoção de mestres leigos para o ensino do Direito, de forma que as conclusões dos acadêmicos fossem as mais próximas de suas próprias essências.

A obra de Rousseau, se escrita nos dias atuais, certamente seria execrada. A propósito, tem-se que não existe um modelo de acadêmico ideal, igual ao que 
TUSSET, Igor Rocha; FORTES, Larissa Borges. As relações entre educação jurídica e poder: reflexões a partir do pensamento de Rousseau e Ranciére. Revista Eletrônica Direito e Política, Programa de Pós-Graduação Stricto Sensu em Ciência Jurídica da UNIVALI, Itajaí, v.10, n.3, $2^{\circ}$ quadrimestre de 2015. Disponível em: www.univali.br/direitoepolitica - ISSN 1980-7791.

propunha Rousseau, que queria que Emilio tivesse as condições ideais para receber uma boa educação. Mesmo longe de modelos ideais, são inegáveis os prejuízos decorrentes do ensino, por exemplo, em grandes grupos. São inegáveis os graves prejuízos à educação, assim como é inegável que muitos dos métodos avaliativos, exigidos enquanto pretenso mecanismo de aperfeiçoamento do ensino, trabalham em sentido contrário, reduzindo, cada vez mais, a capacidade de reflexão, precarizando o ensino.

Deve ser atentado para a necessidade, cada vez mais, de um ensino voltado à reflexão. Um ensino que inverta a lógica do "véu da ignorância" o qual falava Rancière em seu livro, pela qual o professor seria apto à retirada deste véu que desvelaria o saber a seus alunos.

A Educação Jurídica deve lutar contra os dogmas impostos na origem de seu estabelecimento no Brasil. Deve buscar romper com os dogmas da academia, com a "república do saber jurídico", pois, em boa parte das instituições, ainda não foi superada a formatação/repetição de usos e costumes que remontam às épocas mais antigas.

Esta Educação Jurídica deve ter como norte, assim como toda a educação, a emancipação intelectual dos sujeitos envolvidos. Tem como pressuposto a eliminação da figura dos mestres explicadores. É preciso que o professor também deixe claro para seus alunos que também não tem nada a Ihes ensinar, enquanto modelo a ser superado, o de hierarquização dos saberes. Deve demonstrar isto também por suas práticas acadêmicas.

O professor deve figurar como instrumento para a construção do conhecimento jurídico, possibilitando a aproximação entre os conteúdos da sala de aula e a realidade, para a reflexão daqueles que assim o buscarem. Deverá se afastar, ao máximo, da submissão de inteligências, de uma relação de um saber como um poder.

A educação jurídica deve possibilitar ao acadêmico o seu reconhecimento como agente de transformação social, para que este também possa enxergar os demais sujeitos como agentes capazes de ação e transformação social. Ainda que não se tenha a pretensão de se buscar a adoção de um método "ideal" para o estudante de Direito, entende-se que a educação jurídica é capaz de contribuir 
TUSSET, Igor Rocha; FORTES, Larissa Borges. As relações entre educação jurídica e poder: reflexões a partir do pensamento de Rousseau e Ranciére. Revista Eletrônica Direito e Política, Programa de Pós-Graduação Stricto Sensu em Ciência Jurídica da UNIVALI, Itajaí, v.10, n.3, $2^{\circ}$ quadrimestre de 2015. Disponível em: www.univali.br/direitoepolitica - ISSN 1980-7791.

para uma revolução nas estruturas de poder na sociedade, a partir daqueles que já exercem ou possam vir a exercer este poder.

Para além do que decorar regras, tais como o número de dias para a interposição de um determinado recurso, ou a quantidade de verbas rescisórias de uma relação trabalhista, ou ainda, a pena que a legislação prevê para determinado ato considerado como crime, o estudante precisa ter o pleno conhecimento do impacto de suas práticas no meio social em que vive.

\section{REFERÊNCIAS DAS FONTES CITADAS}

BRASIL. Constituição Federal de 1988. Constituição da República Federativa do Brasil, de 05 de outubro de 1988. São Paulo: Saraiva, 2014.

BRASIL. Decreto n.o 3.903, de 12 de janeiro de 1901. Approva o regulamento das Faculdades de Direito. Disponível em < http://legis.senado.gov.br/legislacao/ListaTextoIntegral.action?id=44848\&norma $=60599>$. Acesso em 22.03.2014.

CAMPILONGO, Celso Fernandes. O Direito Na Sociedade Complexa. São Paulo: Max Limonad, 2000.

HOLLANDA, Sérgio Buarque de. Raízes do Brasil. 26 ed. São Paulo: Companhia das Letras, 1995.

MASCARO, Alysson Leandro. Introdução ao Estudo do Direito. São Paulo: Quartier Latin, 2007.

PAIVA, Wilson Alves de. Homem e cidadão na obra pedagógica de Rousseau. In: Cadernos de Educação da FaE PPGE/ Universidade Federal de Pelotas (p. 163-184). Pelotas: julho/dezembro 2008. Disponível em: < http://www2.ufpel.edu.br/fae/caduc/downloads/n31/09.pdf $>$. Acesso em 11.02.2014.

RANCIÈRE, Jacques. O Mestre Ignorante: cinco lições sobre a emancipação intelectual. Tradução: Lilian do Valle. Belo Horizonte: Auténtica, 2002.

ROUSSEAU, Jean-Jacques. Do Contrato Social. Tradução: Rolando Roque da Silva. São Paulo: Hemus, 1981.

. Emílio ou da Educação. Tradução de Sérgio Milliet. Rio de Janeiro: Bertran Brasil, 1995.

SANTOS, Boaventura de Sousa. A crítica da razão indolente: contra o desperdício da experiência. 4 ed. São Paulo: Cortez, 2002. 
TUSSET, Igor Rocha; FORTES, Larissa Borges. As relações entre educação jurídica e poder: reflexões a partir do pensamento de Rousseau e Ranciére. Revista Eletrônica Direito e Política, Programa de Pós-Graduação Stricto Sensu em Ciência Jurídica da UNIVALI, Itajaí, v.10, n.3, $2^{\circ}$ quadrimestre de 2015. Disponível em: www.univali.br/direitoepolitica - ISSN 1980-7791.

SOUZA JÚNIOR, José Geraldo de. Ensino do Direito e Assessoria Jurídica. In. Revista do Saju: Para uma visão crítica e interdisciplinar do direito. Ed. Especial n. ${ }^{\circ}$ 5. Porto Alegre: Faculdade de Direito da UFRGS, 2006.

VERMEREN, Patrice; CORNU, Laurence; BENVENUTO, Andrea. Atualidade de $\mathbf{0}$ Mestre Ignorante. In. Revista Educação e Sociedade, vol 24, n. 82, p. 185202. Campinas: abril de 2003. Disponível em <http://www.redalyc.org/pdf/873/87313720009.pdf>. Acesso em 18.02.2014.

WARAT, Luis Alberto. Territórios desconhecidos: a procura surrealista pelos lugares do abandono do sentido e da reconstrução da subjetividade. coord.: Orides Mezzaroba, Arno Dal Ri Júnior, Aires José Rover, Cláudia Sevilha Monteiro. Florianópolis: Fundação Boiteux, 2004a.

. Epistemologia e ensino do direito: o sonho acabou. coord.: Orides Mezzaroba, Arno Dal Ri Júnior, Aires José Rover, Cláudia Sevilha Monteiro. Florianópolis: Boiteux, 2004b.

WOLKMER, Antônio Carlos. Pluralismo Jurídico: Fundamentos de uma nova cultura no Direito. 3 ed. São Paulo: Alfa-Omega, 2001.

Submetido em: Junho/2015

Aprovado em: Agosto/2015 